\title{
A Breakthrough in Water Purification Using an Oligodynamic Metal and Moringa Oleifera Seed
}

\author{
Alakaparampil Joseph Varkey \\ Department of Physics, University of Swaziland, P/Bag 4 Kwaluseni, Swaziland \\ Email:varkey@uniswa.sz
}

\begin{abstract}
A simple, efficient and stand-alone method for purification of river water using moringa seed powder and copper is discussed. Coagulant property of the seed powder clears turbid raw water and the oligodynamic activity of copper completely destroys E.coli bacteria. Both raw and treated water samples were tested for contaminants to verify the efficacy of the system. Treated water has turbidity in the range 3 NTU - 5 NTU and non-detected $(<1 \mathrm{MPN} / 100$ $\mathrm{mL}$ ) E.coli count making it suitable for drinking. The technique is very cost effective and can be practiced anywhere using locally available materials. It does not require a power source or any technical assistance. Being a stand-alone system the technique exceptionally useful in providing drinking water as an immediate solution in disaster areas affected by cyclone or floods.
\end{abstract}

Key words: water purification, oligodynamic metal, moringa oleifera seed, copper 


\section{Introduction}

Supply of adequate clean water to communities is a problem worldwide, especially in developing countries where rural population depends on water from rivers, dams and streams for domestic use which may contain pathogens and toxic materials. Drinking such contaminated water can lead to severe health problems in the community. Scarcity of clean potable water affects every continent today. According to a recent United Nations report around 1.2 billion people, or almost one-fifth of the world's population, live in areas of water scarcity (UN Report 2015). 783 million people do not have access to clean and safe water worldwide and 319 million people in Sub-Saharan Africa alone are without access to reliable drinking water sources (The Water project 2016). According to World Health Organization, currently nearly 159 million people depend on surface water and globally, at least 2 billion people use drinking water contaminated with faeces (WHO 2017).

Two major aspects of maintaining water quality is the removal of turbidity caused by suspended particles and elimination of pathogens present in raw water. Though turbidity is not a serious health risk, apart from the aesthetic point of view, the suspended particles can shield pathogens and thus interfere with any disinfection process. Pathogens can be viruses, protozoa or bacteria such as $E$. coli, the presence of which in water is an indication of recent contamination from human or animal waste. This being the main source of pathogens, it is customary to test only for E.coli to assess quality for drinking water though other forms of coliforms could be present, but may not be harmful to humans. The conventional method of water purification using aluminium sulphate (alum) as a coagulant to remove turbidity is not easily available to rural communities. If used in large quantity it can cause serious health hazards apart from its environmental effects. The use of expensive chemicals like chlorine to remove pathogenic bacteria from pipe-born water, can also lead to serious health problems. To add to that, in most places in developing countries, such water supply systems do not exist or they are not affordable and as such people depend on river water for all domestic use including drinking and cooking. Other stand-alone water purification systems studied so far for rural communities have limitations of one kind or the other. For instance, solar still can yield pure drinking water, but its operation is dependent on availability of sunshine. Some others are expensive for installation and maintenance like Reverse Osmosis units, some need technical expertise to operate which is not always available in rural areas, and others do not produce $100 \%$ pure water, for example activated carbon or clay pot filters (Varkey and Dlamini, 2010). This paper presents results of an attempt made to purify river water using moringa seed powder to minimize turbidity and copper metal to destroy E.coli bactria.

The technique of water purification using moringa seeds as a coagulant is well known (Francis and Amos 2009; Omodamiro et al. 2014; Aruna and Srilatha 2012; Ndabigengesere and Narasiah, 1998; Eman et al. 2009 ). Moringa seed powder dissolved in a small amount of clean water is added to turbid water from the river. Initially the seed particles are suspended in water. With time, they attract dirt particles increasing their mass and sedimentation takes place by gravity. When sedimentation is complete water can be decanted and filtered through cloth to get clear water. It is believed that the clearing ability of the moringa powder is due to positively-charged protein called the Moringa Oleifera Cationic Protein (MOCP) present in it. Though the powder can clarify water efficiently, there are conflicting reports on their use as an antibacterial agent. Few studies have shown that the seeds have antibacterial property to some extent, while other studies have contradicting results (Broin et al. 2002; Lar et al. 2011; Gustavo et al, 2010; Garima et al. 2011; Gamila et al. 2004; Jabeen and Shahid 2008; Jadhav 2008). There is no evidence that moringa seed can 
destroy water pathogens completely to make treated water suitable for human consumption. A recent attempt to rectify this situation, reports on the use of functionalised, reusable sand ( $f$-sand) which can significantly reduce the bacteria count and at the same time clarify dirty water (Huda et al. 2011). Thought it is workable on a laboratory scale, it is not a viable technique for use by rural population. A similar report on the use of moringa protein adsorbed on rice husk ash also indicates its use as a potential for inactivation of E.coli bacteria by binding them onto the husk surface with a possibility of release back into water and not as a means of bacterial inactivation (John Barajas et al. 2016). Another recent report suggests that the mechanism of bacteria destruction using moringa extract is by membrane fusion (Kevin Shebek et al. 2015). Though it helps to understand the possible mechanism by which MOCP kills bacteria like E.coli on a laboratory environment, it needs further investigation to verify whether or not the process can destroy them completely for use in water purification. In addition, due to complexity involved in the extraction process, from a more practical point of view, it does not appear to be a viable technique for use by rural communities. To make things worse, moringa seed protein is reported to help bacterial re-growth in treated water questioning its viability as a water purifier and preventing its storage for later use. (Huda et al. 2011). It is therefore a challenge to find ways of destroying pathogenic bacteria from river water completely to recommend any system for domestic use.

A viable method for destroying bacteria in raw water is to use the antibacterial (oligodynamic) property of metals (Varkey 2010). Copper is well known for its antibacterial activity. There are several reports on the efficacy of copper surface to destroy bacteria such as Enterococcus, Staphylococcus aureus, Enterobacter aerogenes, Escherichia coli O157, Pseudomonas aeruginosa and Staphylococcus aureus and viruses (International Copper Association 2015; European Copper Institute 2018). It is therefore worthwhile to use copper for water purification as an antibacterial agent combined with moringa seed powder as a coagulant material. A concern of using copper in the purification process may be the possibility of copper toxicity in humans by consuming the treated water. However, it can be ruled out since intake of copper in low doses is not harmful to people (Doug Cornell 2017). Its added advantage is that since copper never wears out it can be reused.

\section{Methods}

Moringa seeds were shelled and crushed in a grinder and sieved using a $0.8 \mathrm{~mm}$ sieve to obtain its powder. Copper wire $1.0 \mathrm{~mm}$ diameter, $50.0 \mathrm{~cm}$ long was obtained and cleaned using abrasive paper and washed in distilled water. It was cut into $1.0 \mathrm{~g}$ to $6.0 \mathrm{~g}$ sizes and was made into spiral shape to fit in the beakers. Raw water was collected from rivers and filtered using a cotton cloth to remove any large particles suspended in it. In the first part of the experiment coagulant property of the moringa seed powder was tested as follows.

\section{Using moringa seed powder}

\section{Step 1}

$800 \mathrm{ml}$ each of raw turbid river water was collected in 6 beakers and $0.2 \mathrm{~g}$ each of the seed powder was sprinkled on their surfaces and stirred vigorously for about 10 seconds and left standing to allow coagulation and sedimentation of any suspended particles. In every one hour, water in each beaker was decanted and filtered using a fine mesh cotton cloth to remove any remaining suspended particles. Turbidity and E.coli of the raw sample and the 6 filtered samples were measured.

\section{Step 2}


Different amounts, $0.1 \mathrm{~g}-0.6 \mathrm{~g}$ in steps of $0.1 \mathrm{~g}$ of the seed powder was added to each sample as before in the 6 beakers and turbidity and E.coli count were done after allowing water to stand for a fixed time of 4 hours which was the minimum time needed to bring down turbidity to the lowest level, got from step 1. Turbidity and E.coli count of raw and filtered samples were measured.

\section{Using moringa seed powder and copper}

Step 3

$800 \mathrm{ml}$ each of raw river water was collected in 6 beakers and $0.2 \mathrm{~g}$ seed powder was sprinkled in each, stirred and left standing for 6 hours. Water was decanted and filtered into 6 beakers and $1.0 \mathrm{~g}-6.0 \mathrm{~g}$ of copper wire in steps of $1.0 \mathrm{~g}$, was immersed in each beaker and left for 6 hours. E.coli count was done in each sample to determine the minimum amount of copper needed to kill all the E.coli bacteria in a sample. The time interval of 6 hours was a random choice to allow enough time for copper reaction to occur.

Step 4

Step 3 was repeated to get 6 beakers of filtered clear water. $4.0 \mathrm{~g}$ (a random choice) of copper wire was immersed in each beaker and E.coli enumeration was done every 1 hour up to 6 hours to determine the minimum time required to kill all of them.

Step 5

Having established the minimum required amount of seed powder, reaction time and copper content to purify one litre of raw water, in the final step, $0.2 \mathrm{~g}$ seed powder was sprinkled and stirred as before in $800 \mathrm{~mL}$ raw water and left standing for 6 hours. Water was then decanted/ filtered with cloth. $4.0 \mathrm{~g}$ of copper wire was immersed in it and left for 5 hours after which it was removed leaving behind clear water. It was tested for turbidity and E.coli count. For all tests a Nephelometer was used for turbidity and E.coli count was done by Colisure method. The whole procedure was done at room temperature of $\sim 20{ }^{\circ} \mathrm{C}-22{ }^{\circ} \mathrm{C}$.

\section{Results and Discussions}

\section{Using moringa seed powder alone}

While using moringa powder, before filtering water was clear at the top and sediments were seen deposited at the bottom of the container. Flocculation and sedimentation was found to be a slow process. Within about the first 30 minutes of adding powder, water changed its colour from reddish/pink to milky/white, but still turbid having turbidity more than that of the raw water. This happens because within this time the seed particles have not yet got enough dirt particles attached to them to have sufficient mass to sediment by gravity. With time, more dirt gets attached to the seed particles and sedimentation starts depositing all the dirt at the bottom leaving clear water on top which can be decanted/filtered. Turbidity of filtered water could go down to less than 3 NTU within 4 hours as shown in Fig. 1. 


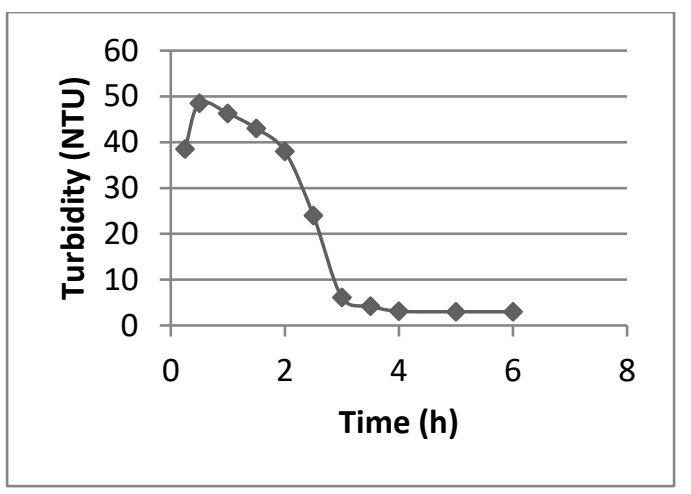

Fig. 1. A typical variation of turbidity with time on addition of $0.25 \mathrm{~g} / \mathrm{L}$ powder

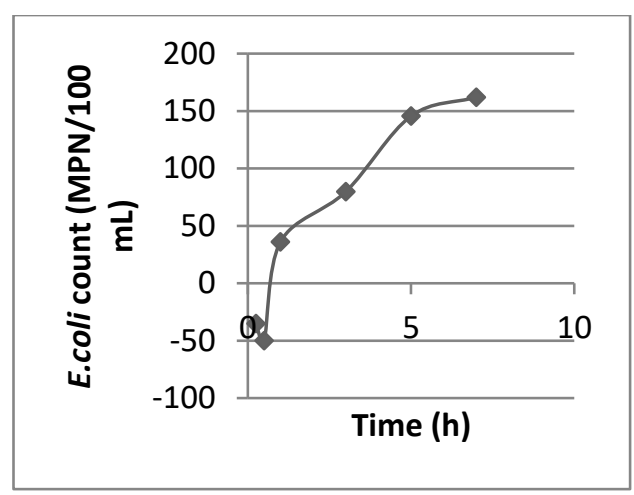

Fig. 2. A typical variation of E.coli with time on addition of $0.25 \mathrm{~g} / \mathrm{L}$ powder

Fig. 2 shows how E.coli count varies with time on addition of $0.25 \mathrm{~g} / \mathrm{L}$ powder. Initially there was a slight decrease in E.coli count which started increasing with time. A possible explanation of this happening is that initially along with the dirt particles the bacteria get attached to moringa proteins and settle down. Negative charge of E.coli facilitates this process. However, after settling down the bacteria are alive (they are only quarantined) and during decanting some of them can get into the water. Under favourable conditions they multiply with time increasing their population. Thus sedimentation and filtering is not enough to kill bacteria completely to make it suitable for drinking. For instance seed extract has been reported to cause a maximum bacterial decay of $93.2 \%$ for E. coli and $96.2 \%$ for B. subtilis. (Saumyadeb et al. 2016) and a 77.27\% reduction (Jadhav et al. 2008). Though 90-99.9\% removal of impurities is reported by moringa seeds, its antimicrobial aspects continue to be researched (Miracle trees 2015). Recently an explanation of the increase in E.coli count was given by (Huda et al. 2011) that the seeds release other water-soluble proteins (apart from the MOCP responsible for coagulation and clarification of the turbid water) and organic matter which increase the concentration of dissolved organic matter (DOM) in water which feed the E.coli bacteria.

Variation of turbidity versus amount of seed powder added to $800 \mathrm{~mL}$ raw water after 4 hours of reaction is shown in Fig. 3. The minimum amount of powder needed to clarify raw water and bring down turbidity $~ 3$ NTU was $0.25 \mathrm{~g} / \mathrm{L}$. Any excess powder is wasted without taking part in the clearing process. Corresponding E.coli change is shown in Fig.4.

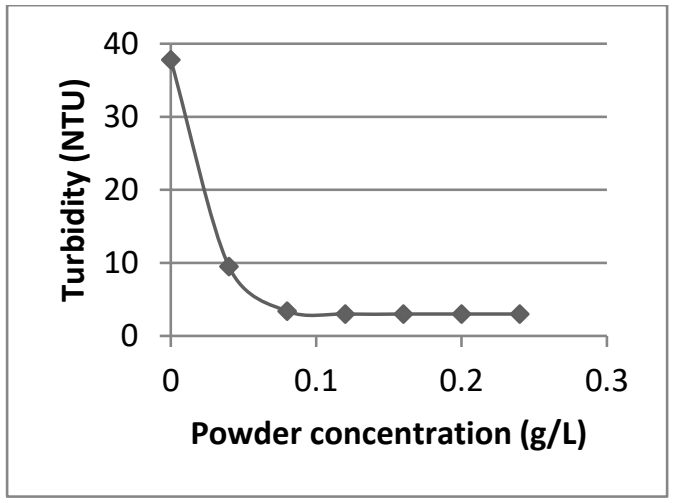

Fig. 3. Variation of turbidity vs. amount of seed powder measured after 4 hours

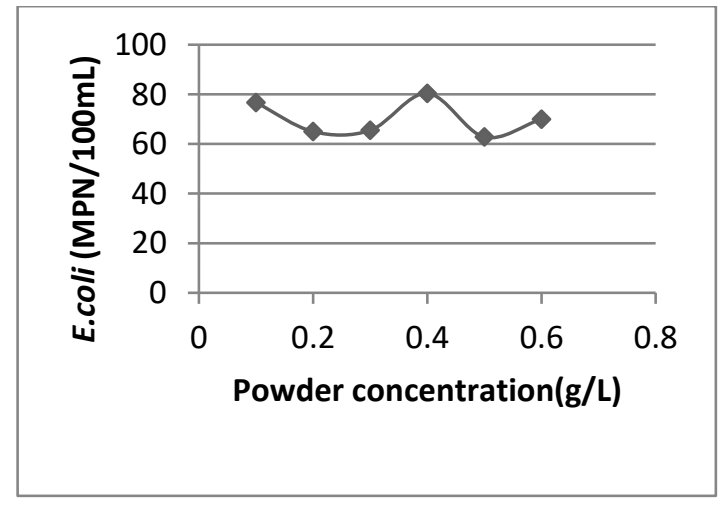

Fig. 4. Variation of E.coli vs. amount of seed powder measured after 4 hours 
As seen from Figs. $2 \&$ 4, variation of E.coli with time or with seed concentration does not have a definite trend, but varies haphazardly, indicating that moringa seed powder does not control the E.coli population in water, meaning that it has no antibacterial property. Being a living organism even a small population of E.coli can be dangerous since they can multiply. Recalling the WHO limit for E.coli count $<1.0 \mathrm{MPN} / 100 \mathrm{~mL}$ for drinking water, the filtered water must be completely free of the bacteria for human consumption. In other words, use of moringa seeds alone as a water purification technique is not fully effective.

\section{Using moringa powder and copper}

As seen in Figs. $1 \& 3$ addition of $0.25 \mathrm{~g} / \mathrm{L}$ seed powder and filtering after 4 hours remove all suspended impurities leaving clear water with turbidity level as low as 3 NTU - 5 NTU which falls within the WHO guidelines for drinking water. Any bacteria still alive in the filtered water is killed by addition of copper reducing the E.coli count to non-detected $(<1$ MPN/100 mL) level. The result confirms the antibacterial property of copper, a very significant aspect in water purification.

Shown in Fig. 5 is E.coli count versus mass of copper for $0.25 \mathrm{~g} / \mathrm{L}$ of moringa seed powder and reaction time of 4 hours. A minimum of $2.0 \mathrm{~g} / \mathrm{L}$ copper is seen needed to disinfect water.

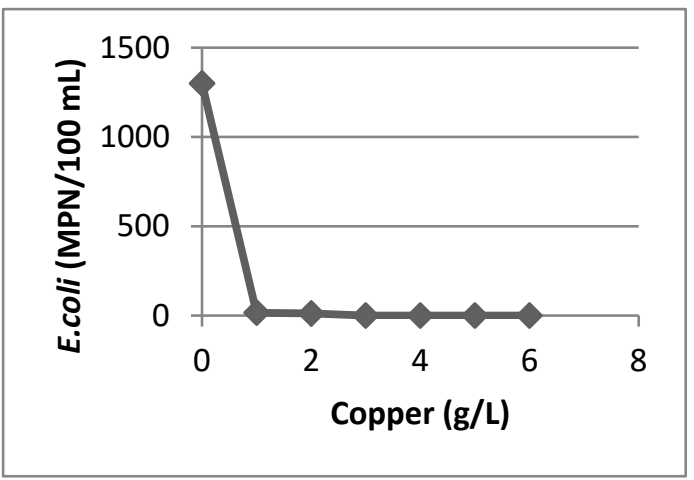

Fig. 5. E.coli count vs. mass of copper for $0.25 \mathrm{~g} / \mathrm{L}$ seed powder and $4 \mathrm{~h}$ reaction time.

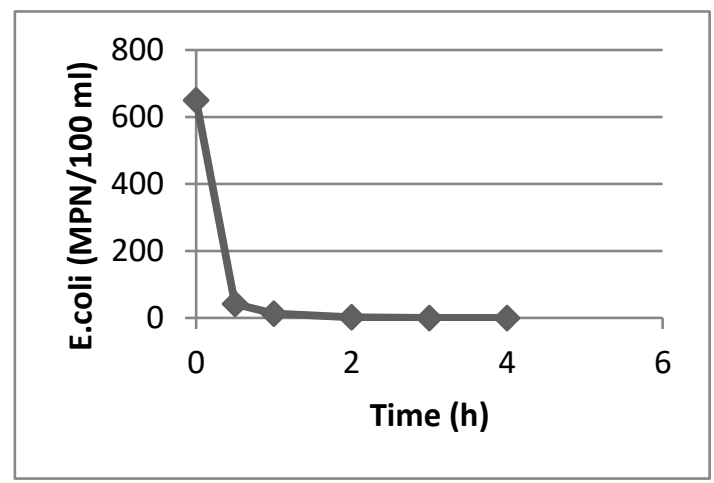

Fig. 6. E.coli count vs. time for $0.25 \mathrm{~g} / \mathrm{L}$ seed powder and $4.0 \mathrm{~g}$ copper.

Fig. 6 shows survival rate of E.coli against time on adding $4.0 \mathrm{~g}$ copper into a sample of filtered water. A minimum of 2.5 hours is required to destroy all the bacteria. These data are important for practical use of the technique to get optimum results. $\mathrm{pH}$ of the treated water was $\sim 6.5$ and conductivity $\sim 108 \mu \mathrm{S} / \mathrm{cm}$ which falls within the accepted $50 \mu \mathrm{S} / \mathrm{cm}-500$ $\mu \mathrm{S} / \mathrm{cm}$ range for drinking water.

The coagulant property of moringa seed and the antibacterial property of copper are mutually exclusive. Copper does not interfere with the sedimentation process of the seed and viceversa. Moringa seed removes suspended pollutants and copper kills bacteria. A combination of the two produces clean drinking water! The ability of cloth to clarify water is dependent on its quality. Fine closely woven cloths are better to retain small particles compared to loosely woven cloths. Filtering through $11 \mu \mathrm{m}$ filter paper has been found to reduce turbidity by nearly $35 \%$ compared to using cloth.

Given below are photographs of raw and treated water: (a) lightly turbid and (b) highly turbid water samples. Initial turbidity or E.coli count does not affect those of the treated water. 

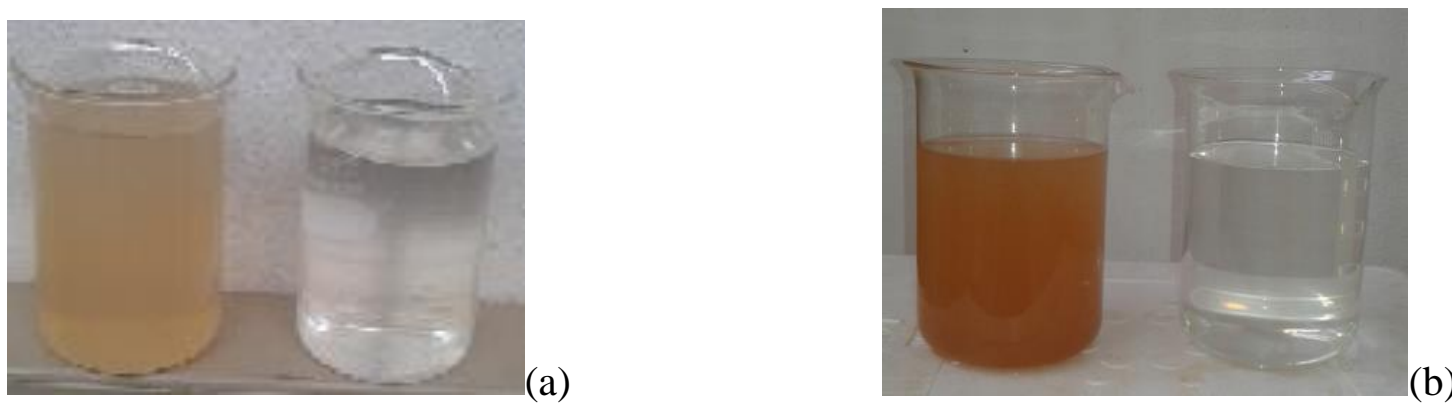

(a) Lightly turbid raw water (turbidity - 65.7 NTU, E.coli - 355 NTU) and treated water (turbidity - 4.5 NTU, E.coli - Not detected)

(b) Highly turbid raw water (Turbidity- 258 NTU, E.coli - 49 MPN/100 mL) and treated water (Turbidity- 4.8 NTU, E.coli - Not detected)

Though the whole process was carried out in a laboratory, it can easily be adapted in rural areas without power supply. A mortar can replace the electric grinder. In place of a precision balance, powder can be weighed by hand as a pinch (measurements show that one pinch of moringa seed powder weighs $0.1-0.12 \mathrm{~g}$ ). A slight difference in the seed mass does not cause significant change in the water quality. Copper wire can be cut and weighed elsewhere and re-used several times since it does not corrode or wear out. It needs only occasional cleaning with an abrasive paper. The only consumable is the seed powder which in many parts of the world is freely available or can be bought at very low cost. A rough cost estimate is $0.5 \mathrm{c} / \mathrm{L}$ whereas commercial bottled water costs $\sim \$ 1.00 / \mathrm{L}$.

\section{Conclusions}

A simple, stand-alone and efficient method for purification of river water has been developed for use in rural communities. The method involves use of moringa seed powder as a coagulant and copper as an antibacterial agent. Treated water has turbidity in the range 3 NTU - 5 NTU and non-detected $(<1 \mathrm{MPN} / 100 \mathrm{~mL})$ E.coli count which fall within accepted guidelines for drinking water. The method can be put into practice anywhere in the world with little effort. It doesn't need any power source or technical assistance for operation. The procedure is quite simple and can be done minimum facilities such as a mortar, a sieve, a length of copper wire and a piece of cloth.

\section{References}

Aruna, M. \& Srilatha, N. (2012). Water clarification using Moringa oleifera Lam. seed as a natural coagulant. Current Biotica 5(4), 472-486.

Broin, M., Santaella C., Cuine S., Kokou K., Peltier G. \& Joët, T. (2002). Flocculent activity of a recombinant protein from Moringa oleifera Lam. seeds. Applied Microbiology and Biotechnology 60(1-2), 114-119.

Doug Cornell (2017) Science confirms copper zaps germs https://www.copperzap.com/science/(accessed 08 February 2018). 
Eman, N. A., Suleyman M. \& Hamzah M.S. (2009). Moringa oleifera seeds as natural coagulant for water treatment. Thirteenth International Water Technology Conference, IWTC 13. Hurghada, Egypt, 163-168.

European copper institute- Antimicrobial Copper is the most effective antimicrobial touch surface Copper continuously kills microbes http://copperalliance.eu/applications/healthcare

Francis, K. A. \& Amos, B. (2009). Effectiveness of moringa oleifera seed as coagulant for water purification. African Journal of Agricultural Research 4 (1), 119-123.

Gamila, H. A., Gamila E. El-T. \& Ali, M.A. (2004). The cytotoxicity and antibacterial efficiency of moringa oleifer seeds extracts. International Journal of Environmental Studies 61(6), 699-708.

Garima M., Pradeep S., Ramesh V., Sunil K., Saurabh S., Jha K. K. \& Khosa, R. L. (2011). Traditional uses, photochemistry and pharmacological properties of Moringa oleifera plant: An overview. Der Pharmacia Lettre 3(2), 141-164.

Gustavo H., Fernandes V., Jozeanne A. M., Angela M. A., Renata, A. C. \& Regine, H. S. (2010). Antibacterial effect (in vitro) of moringa oleifera and annona muricata against gram positive and gram negative bacteria. Revista do Instituto de Medicina Tropical de São Paulo 52(3), 129-132.

Huda A. J., Kristin J. A., Lauren R. M., Darrell V., and Stephanie B. (2011). Antimicrobial Sand via Adsorption of Cationic Moringa oleifera Protein; Langmuir, 28 (4), 2262-2268.

International Copper Association 2015. Antimicrobial Copper.

https://www.antimicrobialcopper.org/us/what-is-antimicrobial-copper (accessed 08 February 2018)

Jabeen, R. \& Shahid, M. 2008. Microscopic evaluation of the antimicrobial activity of seed extracts of Moringa oleifera. Pakistan Journal of Botany 40(4),1349-1358.

Jadhav, S. M., Bipinraj, N. K., Milind R.G. (2008). Moringa oleifera seed as antibacterial agent in water treatment. National Conference on Household Wake Treatment Technology. Hindustan College of Science and Technology, Farah, Mathura. 24-25 July 2008.

John Barajas, Jana Latayan, Sheree Pagsuyoin, Florinda Bacani, Joost Santos, Raymond Tan, Aileen Orbecido, Luis Razon, Michelle Almendrala. Water disinfection using moringa protein adsorbed on rice husk ash. Proc. DLSU Research Congress, De La Salle University, Manila, Philippines March 7-9, 2016, (4) 16-19

Kevin S., Allen B.S., Ian S., Kathleen L., Stephanie V., \& Manish K 2015. The Flocculating Cationic Polypetide from Moringa oleifera Seeds Damages Bacterial Cell Membranes by Causing Membrane Fusion, Langmuir 31(15), 4496-4502

Lar, P. M., Ojile, E. E., Dashe, E. \& Oluoma, J. N. 2011. Antibacterial activity of Moringa oleifera seed extracts on some gram negative bacterial isolates. African Journal of Natural Sciences 14: 5762.

Miracle Trees 2015. Moringa Water Purification http://miracletrees.org/moringa_water_purification.html. Accessed 08 February 2018. 
Ndabigengesere, A. \& Narasiah, K. S. 1998. Quality of water treated by coagulation using Moringa oleifera seed. Water Research 32(3) 781-791.

Omodamiro, O. D., Nwankwo, C. I. and Ejiofor, E.U. 2014. Antimicrobial and coagulant property of Moringa oleifera seed in Water Purification, Scholars Journal of Agriculture and Veterinary Sciences 1(4B), 279-287.

Saumyadeb Dasgupta, Naga Siva Kumar Gunda, Sushanta K. Mitra 2016. Evaluation of the antimicrobial activity of Moringa oleifera seed extract as a sustainable solution for potable water Royal Society of Chemistry (RSC) Advances 6 (31), 25918-25926

The water project (2017) Facts about Water, Statistics of the Water Crisis, https://thewaterproject.org/water-scarcity/water_stats, (Last Update: 8/31/2016). Accessed 31 Dec 2017.

UN Water (2014) Water for Life, 2005-2015, Last updated: 2014/11/24;

http://www.un.org/waterforlifedecade/scarcity.shtml. Accessed 30 December 2017.

Varkey, A. J. 2010 Antibacterial properties of some metals and alloys in combating coliforms in contaminated water. Scientific Research and Essays 5 (24), 3834-3839.

Varkey, A.J. and Dlamini, M.D. 2010 Indigenous porous pot water filter for rural communities in Swaziland. UNISWA Research Journal of Agriculture, Science and Technology 13(1) 61-68.

WHO 2017. Drinking-water, Fact sheet. Updated July 2017, http://www.who.int/mediacentre/factsheets/fs391/en/ World Health Organization, Geneva, Switzerland. Accessed 30 December 2017.

\section{Acknowledgement}

The author wishes to acknowledge support from the Department of Physics, University of Swaziland, for providing laboratory facilities to carry out this project. 